\title{
Alasan mahasiswa fakultas kedokteran gigi tidak menggunakan gigitiruan
}

\section{Eri H. Jubhari}

Bagian Prostodonsia

Fakultas Kedokteran Gigi Universitas Hasanuddin

Makassar, Indonesia

\begin{abstract}
Edentulous state causes disorders in chewing, esthetic, phonetic, temporomandibular joint, and the vinicity tissue. As dental students, they must have to replace their teeth with denture. This study aimed to know the reason why dental students of Hasanuddin University didn't use denture. This descriptive study involved 30 samples based on purposive sampling technique. Data was obtained from questionnaire and examination of oral cavity. The result showed that 23 samples wanted to use denture, and 26 samples said that the denture was necessary. The reasons of not using denture were as follows: no time, not disturbed, expensive, fear, and just for orthodontic treatment. It can be concluded that most respondents had known the importance of using denture. However, the behavior of using denture had not yet existed because of external and internal factor. For that, it is suggested to socialize the imprtance of using denture.
\end{abstract}

Key word: dental student, denture

\begin{abstract}
ABSTRAK
Kehilangan gigi menyebabkan gangguan fungsi pengunyahan, fonetik, estetik, sendi temporomandibula, dan jaringan sekitar gigi yang hilang. Seharusnya, bagi mahasiswa kedokteran gigi, individu yang kehilangan gigi akan menggantinya dengan gigitiruan. Penelitian ini bertujuan untuk mengetahui alasan mahasiswa FKG Unhas tidak menggunakan gigitiruan. Dengan menggunakan teknik purposive sampling, penelitian deskriptif ini mengikutkan 30 sampel. Data diperoleh melalui pengisian kuesioner dan pemeriksaan rongga mulut. Hasil penelitian menunjukkan 23 sampel ingin menggunakan gigitiruan, 26 menyatakan gigitiruan perlu. Sedangkan alasan tidak menggunakan gigitiruan adalah belum sempat, tidak terganggu, mahal, takut, dan hanya untuk alasan ortodonsi. Dari penelitian ini dapat disimpulkan bahwa sebagian besar responden sudah mengetahui tentang perlunya penggantian gigi yang hilang. Meskipun demikian, perilaku untuk menggunakan gigitiruan belum ada karena dipengaruhi oleh faktor eksternal dan internal. Penilaian mereka terhadap keuntungan dan kerugian menjadi hal utama yang menentukan mereka akan menggunakan gigitiruan atau tidak. Untuk itu disarankan perlunya sosialisasi penggunaan gigitiruan Kata kunci: mahasiswa fakultas kedokteran gigi, gigitiruan
\end{abstract}

Koresponden: Eri H. Jubhari, Bagian Prostodonsia, Fakultas Kedokteran Gigi Universitas Hasanuddin, Jl. Kandea No.5, Makassar, Indonesia.

\section{PENDAHULUAN}

Bagi sebagian besar orang, masalah kesehatan gigi dianggap sebagai hal yang sepele dan kadang- kadang kurang diperhatikan. Tetapi anggapan ini tidak sepenuhnya benar.

Menurut Stoll, ${ }^{1}$ gigi merupakan sumber dari 
berbagai gangguan, baik secara fisik maupun mental. Sejak awal kehidupan, gigi sudah dapat menyebabkan ketidaknyamanan. Pada awalnya, seorang bayi merasa senang saat mengisap, tetapi kesenangan itupun hilang ketika ia mulai mempunyai gigi. Akan tetapi, seseorang mengalami ketakutan yang luar biasa apabila gigi sulungnya tanggal, hingga kemudian mendapat pengertian dari orang tuanya bahwa hal itu merupakan proses alamiah dalam pertumbuhan. Pada dasarnya, setiap orang pasti merasa takut kehilangan salah satu bagian dari anggota tubuhnya, termasuk gigi.

Jika seseorang kehilangan satu atau lebih giginya, maka ia juga akan kehilangan kemampuan untuk melakukan aktivitas pengunyahan dan berbicara serta dapat mempengaruhi penampilannya. McGuire $^{2}$ menyebutkan bahwa kehilangan gigi dapat menyebabkan permasalahan yang unik dalam hal penyikatan gigi. Seseorang yang kehilangan giginya juga harus memberikan perhatian khusus tidak hanya pada gigi-gigi di sebelah ruang yang kosong akibat pencabutan, tetapi juga gigi yang berada di atas atau di bawah ruang tersebut. Karena secara langsung gigi atas atau gigi bawah tidak lagi mempunyai antagonis, maka gigi tersebut akan lebih mudah mengalami karies dan kerusakan pada jaringan pendukungnya sehingga proses self-cleansing tidak dapat berjalan secara adekuat.

Kehilangan gigi merupakan penyebab utama dari perubahan nutrisi seseorang. Hal tersebut menyebabkan seseorang menjadi susah untuk mengunyah makanan tertentu seperti daging, buah yang keras dan sayuran. Selain itu, kehilangan gigi juga akan mempengaruhi cara berbicara seseorang, karena tanpa gigi kemungkinan besar ia akan mengalami kesulitan dalam mengucapkan kata-kata. $^{3}$
Tidak dapat dipungkiri bahwa kehilangan gigi merupakan suatu keadaan yang sering ditemukan di mana saja, dan melihat akibatnya jika tidak diganti cukup berisiko seperti yang telah disebutkan di atas, maka sudah seharusnya gigi yang hilang tersebut diganti dengan gigitiruan. Namun pengalaman klinis yang sering dijumpai adalah ruang bekas pencabutan tersebut dibiarkan kosong tanpa perawatan. Ada beberapa hal yang mempengaruhi seseorang untuk tidak mengganti giginya yang hilang, salah satu di antaranya adalah pola pikir seseorang. Ada yang menganggap kehilangan gigi, apalagi kalau hanya satu gigi dan dirasakan tidak mengganggu merupakan hal yang biasa sehingga merasa tidak perlu untuk memakai gigitiruan. Ada yang acuh terhadap giginya yang hilang itu karena orang tersebut berpikir kalau gigi belakang yang hilang tidak akan mengganggu estetiknya, dan ada juga yang memang mengerti perlunya memasang gigitiruan tetapi terhambat dengan masalah lain misalnya ekonomi.

Banyak hal yang dapat mempengaruhi pola pikir, sikap dan perilaku seseorang seperti penghasilan, pengalaman yang diperoleh semasa kecil, cita-cita, keadaan sosial budaya di sekitarnya termasuk norma-norma dan nilai-nilai yang ada dalam lingkungan keluarga maupun lingkungan masyarakat, terutama pendidikan. Pendidikan merupakan proses perubahan sikap dan tata laku seseorang atau sekelompok orang dalam usaha mendewasakan manusia melalui proses pengajaran dan latihan serta cara mendidik. ${ }^{4}$ Makin tinggi tingkat pendidikan seseorang, maka kesadaran dan pengetahuan tentang perawatan gigi akan meningkat pula sehingga prevalensi penyakit gigi dan mulut, seperti penyakit periodontal yang merupakan penyebab utama kehilangan gigi semakin rendah. ${ }^{5}$
Mahasiswa
Fakultas
Kedokteran
Gigi 
Universitas Hasanuddin khususnya tingkatan kedua ke atas, dapat dikatakan memiliki tingkat pemahaman tentang kesehatan gigi dan mulut yang baik karena lebih banyak mendapatkan pengetahuan tentang ilmu-ilmu kedokteran gigi. Lain halnya dengan mahasiswa Fakultas Kedokteran Gigi tingkatan pertama yang masih dalam tahap awal pemahaman tentang kesehatan gigi dan mulut.

Dengan dasar untuk mengetahui alasan Mahasiswa Fakultas Kedokteran Gigi Universitas Hasanuddin tingkatan pertama tidak mengganti giginya yang telah dicabut, maka pada makalah ini akan dilaporkan hasil penelitian mengenai alasan mahasiswa Fakultas Kedokteran Gigi Universitas Hasanuddin tidak menggunakan gigitiruan.

\section{BAHAN DAN METODE}

Penelitian deskriptif ini dilakukan pada akhir semester awal 2005/2006. Populasi adalah mahasiswa FKG Unhas tingkat pertama. Dengan menggunakan purposive sampling ${ }^{6}$ berdasar kriteria dan karakteristik tertentu yang telah dibuat, yaitu telah mengalami kehilangan satu atau lebih gigi, diperoleh sampel sebesar 30 orang. Teknik pengumpulan data yang digunakan dalam penelitian ini adalah teknik komunikasi, dilakukan dengan menggunakan kuesioner dan melakukan wawancara dan pemeriksaan langsung pada rongga mulut.

Setelah pengisian kuesioner dan pemeriksaan rongga mulut, ada beberapa responden yang memberikan jawaban yang bertentangan, maka perlu dilakukan wawancara langsung dengan mahasiswa bersangkutan. Setelah dilakukan pemeriksaan dan wawancara secara langsung, diperoleh data 31 mahasiswa yang telah kehilangan gigi.
Data yang diperoleh dianalisis secara deskriptif dengan membuat uraian secara sistematis mengenai hasil penelitian kemudian didistribusikan ke dalam bentuk tabel.

\section{HASIL PENELITIAN}

Dari penelitian tentang alasan mahasiswa tingkat pertama Fakultas Kedokteran Gigi Universitas Hasanuddin tidak menggunakan gigitiruan diperoleh hasil seperti yang tampak pada tabel 1. Semua sampel tidak menggunakan gigitiruan, meskipun 26 diantaranya memiliki kerabat yang memakai gigitiruan dengan berbagai variasi hubungan kekerabatan. Akan tetapi, seandainya suatu saat ada gigi yang hilang/dicabut, ternyata 23 sampel menyatakan akan menggunakan gigitiruan. Pada tabel 2 tampak bahwa $96,67 \%$ responden yang mengalami edentulus menjawab perlu untuk mengganti gigi yang hilang.

Tabel 3 memberikan gambaran tentang hal-hal yang menjadi pertimbangan sehingga mahasiswa sehingga tidak menggunakan gigitiruan. Hasilnya menunjukkan bahwa sebanyak 12 orang yang beralasan tidak mempunyai waktu atau belum sempat untuk berkunjung ke dokter gigi, 12 orang dengan alasan merasa tidak terganggu dengan kondisi kehilangan gigi atau masa bodoh, sebanyak 5 orang terhambat dengan biaya pembuatan gigitiruan yang mahal, 1 orang yang takut menggunakan gigitiruan karena mendengar keluhan ketidaknyamanan menggunakan gigitiruan dari anggota keluarga, dan tidak menggunakan gigitiruan karena alasan pencabutan gigi dilakukan untuk perawatan ortodonsi sebanyak 6 orang. 
Tabel 1. Jawaban responden terhadap pertanyaan pada lembaran kuesioner

\begin{tabular}{|c|c|c|c|c|c|c|c|c|}
\hline \multirow{2}{*}{ No } & \multirow{2}{*}{ Pertanyaan } & \multicolumn{3}{|c|}{ Jawaban } & \multicolumn{2}{|c|}{ Jawaban } & \multicolumn{2}{|c|}{ Jawaban } \\
\hline & & $\mathrm{Ya}$ & Tidak & Pernah & Ya & Tidak & Ya & Tidak \\
\hline 1. & $\begin{array}{l}\text { Apakah gigi yang hilang telah diganti dengan } \\
\text { gigitiruan? }\end{array}$ & - & 30 & - & & & & \\
\hline 2. & $\begin{array}{l}\text { Adakah kerabat yang memakai gigitiruan? } \\
\text { - } \text { Ayah } \\
\text { - } \text { Ibu } \\
\text { - } \text { Kakek } \\
\text { - } \text { Nenek } \\
\text { - } \text { Paman } \\
-\quad \text { Bibi } \\
\text { - } \quad \text { Sepupu } \\
-\quad \text { Kakak }\end{array}$ & & & & $\begin{array}{r}26 \\
6 \\
5 \\
4 \\
14 \\
3 \\
2 \\
1 \\
1 \\
\end{array}$ & 4 & & \\
\hline 3. & $\begin{array}{l}\text { Seandainya suatu saat gigi Anda ada yang } \\
\text { dicabut, akankah Anda memakai gigitiruan? }\end{array}$ & & & & & & 23 & 7 \\
\hline
\end{tabular}

Keterangan: Pertanyaan nomor 2, terdapat mahasiswa yang menyebutkan lebih dari satu hubungan kekerabatan.

Tabel 2. Distribusi jawaban responden tentang perlu tidaknya gigi yang hilang diganti

\begin{tabular}{|c|c|c|c|c|}
\hline \multirow{2}{*}{ Pertanyaan } & \multicolumn{3}{|c|}{ Kehilangan gigi } \\
\cline { 2 - 4 } & \multicolumn{2}{|c|}{ Perlu } & \multicolumn{2}{c|}{ Tidak perlu } \\
\hline \multirow{2}{*}{$\begin{array}{c}\text { Perlukah gigi yang hilang diganti dengan } \\
\text { gigitiruan }\end{array}$} & 29 & $96,67 \%$ & 1 & $3,33 \%$ \\
\hline
\end{tabular}

Tabel 3. Distribusi hal-hal yang menjadi pertimbangan sehingga tidak menggunakan gigitiruan

\begin{tabular}{|c|l|c|}
\hline No. & \multicolumn{1}{|c|}{ Alasan } & $\begin{array}{c}\text { Jumlah } \\
\text { (orang) }\end{array}$ \\
\hline 1. & Tidak ada waktu/belum sempat & 12 \\
\hline 2. & Tidak terganggu/Tidak perlu/masa bodoh & 12 \\
\hline 3. & Biaya pembuatan gigitiruan mahal & 5 \\
\hline 4. & Takut memakai gigitiruan & 1 \\
\hline 5. & Hanya untuk alasan ortodonsi & 6 \\
\hline & Jumlah & 36 \\
\hline
\end{tabular}

Keterangan: terdapat mahasiswa yang menjawab kuesioner lebih dari satu alasan.

\section{PEMBAHASAN}

Banyak hal yang dapat menyebabkan hilangnya gigi, di antaranya penyakit periodontal, karies, trauma/kecelakaan, dan alasan perawatan ortodonsi. Akan tetapi menurut Odusanya, ${ }^{7}$ dua penyebab utama kehilangan gigi, yaitu penyakit periodontal dan karies gigi.
Pencabutan gigi tanpa penanganan lebih lanjut berisiko menimbulkan banyak masalah sehingga malah membutuhkan perawatan yang lebih luas. Namun pengalaman klinis yang sering dijumpai adalah ruang bekas pencabutan tersebut dibiarkan kosong tanpa perawatan. Ada beberapa hal yang mempengaruhi keputusan seseorang untuk tidak 
mengganti giginya yang hilang, salah satu di antaranya adalah pola pikir seseorang.

Banyak hal yang dapat mempengaruhi pola pikir seseorang seperti pendidikan, pengetahuan, sikap dan perilaku, penghasilan, sikap orang tua, dan pelayanan kesehatan.

Faktor-faktor yang mempengaruhi pola pikir seseorang terhadap penggantian gigi yang hilang adalah faktor predisposisi, terdiri atas pendidikan, pengetahuan, perilaku, kepribadian seseorang, dan jenis kelamin. Faktor pendukung, terdiri atas pendapatan keluarga, ketersediaan waktu, dan pelayanan kesehatan, dan faktor pendorong, terdiri atas sikap petugas dan sikap orang tua. ${ }^{8}$

Contoh bahwa faktor-faktor tersebut dapat mempengaruhi pola pikir seseorang untuk menggunakan gigitiruan atau tidak, misalnya seseorang kehilangan gigi dan mengetahui akibatakibat yang ditimbulkan apabila tidak segera dilakukan perawatan, akan mempertimbangkan untuk memakai gigitiruan. Sebaliknya, orang yang tidak mengetahui dampak negatif kehilangan gigi, akan membiarkannya kosong tanpa perawatan. Pengetahuan yang dimiliki tersebut tentunya dipengaruhi oleh pendidikan yang dimiliki, baik yang diperoleh dari bangku sekolah, ataupun lingkungan keluarga.

Selanjutnya, faktor yang menjadi pertimbangan seseorang untuk menggunakan gigitiruan atau tidak menggunakan, adalah pendapatan keluarga. Meskipun seseorang tahu dan sadar akan perlunya penggantian gigi yang hilang, tetapi jika pendapatan keluarga hanya cukup untuk memenuhi kebutuhan pokoknya saja, maka pertimbangan untuk hal itu akan dikesampingkan. Selain itu, ketersediaan waktu dan tempat layanan kesehatan seperti puskesmas, rumah sakit, poliklinik, dan dokter praktik swasta, dan sebagainya, juga mempengaruhi seseorang untuk memutuskan menggunakan gigitiruan atau tidak. Seseorang yang mau menggunakan gigitiruan tidak hanya karena ia tahu dan sadar manfaat penggantian gigi yang hilang, melainkan ia juga dengan mudah harus dapat mengakses tempat yang tepat untuk memasang gigitiruan. Faktor sikap dan perilaku tokoh masyarakat, tokoh agama, para petugas termasuk petugas kesehatan juga menjadi faktor yang cukup berpengaruh pada seseorang untuk menggunakan gigitiruan atau tidak. Seseorang atau masyarakat kadang-kadang bukan hanya perlu pengetahuan, sikap positif, dan dukungan fasilitas saja, melainkan diperlukan perilaku contoh dari para tokoh masyarakat, tokoh agama, para petugas, lebih-lebih para petugas kesehatan.

Dari konsep di atas terlihat pola pikir berperan besar dalam penggantian gigi yang hilang dengan gigitiruan. Meskipun diketahui banyak pengaruh negatif jika tidak menggunakan gigitiruan, namun masih banyak orang yang mengabaikannya. Hal ini mencetuskan perlunya sosialisasi dan atau penyuluhan dalam hal penggunaan gigitiruan.

Dari hasil penelitian tentang alasan mahasiswa FKG UNHAS tidak menggunakan gigitiruan, 2/3 sampel memiliki orang tua yang mempunyai kendala. Akan tetapi, keadaan sosioekonomi suatu keluarga juga dapat diukur melalui tingkat pendidikan, dan pendapatan keluarga. Faktorfaktor tersebut saling terkait satu dengan lainnya. Jenis pekerjaan misalnya, yang dapat dipengaruhi oleh tingkat pendidikan, atau pendapatan keluarga yang dapat dipengaruhi oleh pekerjaan. ${ }^{6}$ Suasana dan keadaan keluarga juga turut menentukan kondisi kesehatan gigi dan mulut seorang anak atau remaja, dalam hal ini menentukan keputusan untuk menggunakan gigitiruan. ${ }^{9}$

Tunjangan kesehatan dari tempat bekerja mempengaruhi minat anggota keluarga untuk mencari tempat layanan kesehatan. ${ }^{10}$ 
Dari tabel 2, tampak adanya kontradiksi, yaitu mereka akan menggunakan gigitiruan jika suatu saat kehilangan gigi. Akan tetapi tidak satupun dari mahasiswa tersebut yang telah menggunakan gigitiruan. Tampak bahwa mereka telah memahami makna gigitiruan. Mungkin dari situasi mereka sebagai mahasiswa FKG. Akan tetapi pengaruh dari keluarga dan lingkungan ternyata lebih kuat dari pada kondisi mereka sebagai mahasiswa tingkat pertama.

Perilaku memegang peranan penting dalam mempengaruhi status kesehatan gigi dan mulut, karena disamping mempengaruhi status kesehatan gigi dan mulut secara langsung, perilaku dapat mempengaruhi faktor lingkungan maupun layanan kesehatan. $^{11}$

Bloom yang dikutip oleh Astoeti, ${ }^{11}$ menyebutkan bahwa perilaku dibagi menjadi 3 bagian yaitu kognitif, afektif, dan psikomotorik. Selanjutnya Sears dkk, ${ }^{12}$ menyebutkan bahwa kognitif terdiri dari pengertian yang dimiliki seseorang mengenai objek tertentu, yaitu fakta, pengetahuan, dan keyakinan tentang objek. Afektif terdiri dari seluruh perasaan atau emosi seseorang terhadap objek, terutama penilaian. Sedangkan psikomotorik terdiri dari praktik atau tindakan yang dilakukan seseorang.

Berdasarkan ketentuan di atas, tampak bahwa sebagian besar responden sudah mengetahui perlunya penggantian gigi yang hilang, sehingga dalam hal ini berperan komponen kognitif. Kini mereka merasa bahwa penggantian gigi yang hilang sangat bermanfaat dan dapat menghindarkan mereka dari pengaruh negatif kehilangan gigi, sehingga yang berperan dalam hal ini adalah komponen afektif. Muncul pertanyaan, "apakah mereka akan menggunakan gigitiruan?" Hasil penelitian menunjukkan tidak seorangpun menggunakan gigitiruan. Dengan kata lain, serupa dengan pendapat Sears $\mathrm{dkk}^{12}$ komponen psikomotorik dari perilaku tidak selalu sesuai dengan komponen kognitif dan afektif.

Adanya ketidaksesuaian antara komponen perilaku ini mungkin disebabkan oleh beberapa hal yang menjadi pertimbangan mengapa mereka tidak mengganti giginya (tabel 3).

Sears $\mathrm{dkk}^{12}$ juga menyebutkan bahwa perilaku seseorang memang dipengaruhi oleh pengetahuan atau pemahaman yang dimilikinya, namun arah umum perilaku terutama dipengaruhi oleh keseluruhan penilaian orang tersebut, apakah dia menilai hal itu sebagai hal yang menguntungkan atau merugikan. Seseorang bertindak berdasarkan keuntungan dan kerugian yang diperoleh dari setiap perilaku.

Dalam kasus ini, para responden mengetahui manfaat menggunakan gigitiruan juga merasa bahwa untuk mendapatkan manfaat tersebut mereka harus mengorbankan lebih banyak hal. Mereka merasa keuntungan dan kerugian yang diperoleh tidak sebanding.

Dari tabel 1 tampak bahwa sebagian besar responden mempunyai kerabat yang menggunakan gigitiruan. Orang yang berada di sekitar individu sangat mempengaruhi individu yang bersangkutan, untuk menggunakan gigitiruan atau tidak. Dalam perkembangan anak, peranan keluarga, terutama ayah dan ibu, sangat penting dan menentukan pembentukan kepribadiannya di masa depan. ${ }^{9}$

Pada tabel 2, dari jawaban responden mengenai perlu/tidaknya gigi yang hilang diganti dengan gigitiruan, tergambar bahwa sebagian besar responden, baik yang mengalami edentulus maupun yang tidak mengalami edentulus, menjawab perlu untuk menggantikan gigi yang hilang.

Meskipun umumnya responden menjawab perlu untuk menggantikan gigi yang hilang, namun kenyataannya, tidak atau belum ada yang 
menggunakan gigitiruan (tabel 2). Adapun hal-hal yang menjadi pertimbangan mahasiswa tersebut tidak atau belum menggunakan gigitiruan terlihat pada tabel 3, yaitu karena tidak ada waktu atau belum sempat untuk berkunjung ke dokter gigi karena sibuk dan tempat layanan kesehatan yang diperlukan jauh letaknya, atau tidak jarang pula yang memprioritaskan tugas/kegiatan lain yang dianggap lebih penting daripada masalah kesehatan gigi. $^{10}$ Selain itu, ada yang merasa kegiatan sehari-hari tidak terganggu dengan kondisi kehilangan gigi, bahkan jika ada keluhan rasa sakit dan ketidaknyamanan sering diabaikan karena mereka beranggapan rasa sakit yang dideritanya akan hilang dengan sendirinya. ${ }^{10}$ Biaya perawatan tetap merupakan kendala yang tidak dapat diatasi oleh kebanyakan orang. Meskipun terdapat banyak individu yang mampu, namun faktor biaya tetap tidak dapat dihilangkan. Kalaupun mendapat tunjangan asuransi kesehatan, banyak yang tidak memanfaatkannya karena pengurusan yang cukup rumit dan layanan yang tidak memuaskan dari petugas administrasi. ${ }^{10,13}$ Ada juga sampel yang merasa takut menggunakan gigitiruan karena adanya informasi tentang ketidaknyamanan menggunakan gigitiruan dari salah satu anggota keluarga.

Dari hasil penelitian tersebut, maka dapat disimpulkan sebagian besar responden sudah mengetahui tentang perlunya penggantian gigi yang hilang. Meskipun demikian, belum/tidak ada mahasiswa dalam sampel penelitian ini yang menggunakan gigitiruan. Sebagai mahasiswa FKG, angkatan pertama telah menunjukkan pemahaman yang benar tentang penggantian gigi setelah dicabut. Meskipun demikian, perilaku untuk menggunakan gigitiruan belum ada karena dipengaruhi oleh faktor eksternal dan internal. Faktor eksternal berupa keluarga, waktu, ekonomi, pendidikan, sikap petugas, dan lingkungan. Faktor internal meliputi pengetahuan, pola pikir, dan kepribadian. Dari faktor-faktor tersebut, tidak tersedianya waktu menjadi faktor eksternal utama yang menjadi pertimbangan untuk menggunakan gigitiruan. Sedangkan pola pikir yang merupakan faktor internal, tampak memegang peranan penting. Penilaian mereka terhadap keuntungan dan kerugian menggunakan gigitiruan menjadi hal utama yang menentukan mereka akan menggunakan gigitiruan atau tidak.

Dari simpulan penelitian ini, disarankan perlunya sosialisasi dan atau penyuluhan dalam hal penggunaan gigitiruan. Selain itu dibutuhkan kerjasama yang melibatkan orang tua/keluarga. Orang tua/keluarga jangan menunjukkan rasa takut yang berlebihan di depan anak dan sebaiknya anak sudah diperkenalkan tentang perawatan gigi sedini mungkin.

\section{DAFTAR PUSTAKA}

1. Stoll FA. Dental health education, $5^{\text {th }}$ ed. Philadelphia: Lea \& Febiger; 1977.p.17, 24.

2. McGuire. Tooth fitness your guide to healthy teeth. Nevada: St. Michaels's Press; 1994.p.139

3. University of Texas Health Science Center at San Antonio. Effects of tooth loss. 2001. Available from:URL: http://www.teachhealthk12.uthsca.edu/pa/pa09/pa09pdf/0906LSN.pdf. Accessed November 19,2005.

4. Budiharto. Perilaku kelompok masyarakat rendah di perkotaan terhadap kesehatan gigi tahun 1999. J Kedokteran Gigi Universitas Indonesia 2000; 7 (2):40-1.

5. Carranza FA. Glickman's clinical peridontology, $9^{\text {th }}$ ed. London: W.B. Saunders Co.; 2002. p.90.

6. Notoadmodjo S. Metodologi penelitian kesehatan. Jakarta: PT Rineka Cipta ; 2005. hlm. 68, 70, 88-9.

7. Odusanya SA. Tooth loss among Nigerians:causes and pattern of mortality. Int J Oral Maxillofac Surg 1987; 16(2):184-9. Available from: http://www.ncbi.nlm.nih.gov/entrez/query.fcg $\mathrm{i}$ ?cmd=Retrieve $\& \mathrm{db}=$ Pubmed $\%$ list- 
uids $=10946463 \&$ dopt $=$ Citation. $\quad$ Accessed Desember 11, 2005.

8. Departemen Kesehatan RI. Penyuluhan Kesehatan Masyarakat. Jakarta: Depkes RI; 1992.hlm.3.

9. Purwanto MN. Psikologi pendidikan. Bandung : PT Remaja Rosdakarya ; 2002. hlm. 104, 158, 161.

10. Notoadmodjo S. Pendidikan dan perilaku kesehatan. Jakarta : PT Rineka Cipta; 2003. hlm. 10, 13, 121, 124-5, 179, 195-6, 202
11. Astoeti TE, Boesro S. Pengaruh tingkat pengetahuan terhadap kebersihan gigi dan mulut murid-murid SDN DKI Jakarta. Jurnal Kedokteran Gigi Universitas Sumatera Utara 2003;2(8):149.

12. Sears DO, Freedman JL, Peplau LA. Psikologi sosial. Alihbahasa: Adryanto M, Soekrisno S. Jakarta: Erlangga; 1994. hlm. 14, 138-41

13. Azwar A. Pengantar administrasi kesehatan, $3^{\text {rd }}$ ed. Jakarta: Binarupa Aksara; 1996. hlm. 157-8. 